\title{
MOTIF, FUNGSI, DAN KEARIFAN LOKAL BEBERAPA LEGENDA DI KOTA SAWAHLUNTO
}

\section{MOTIVES, FUNCTIONS, AND LOCAL WISDOM OF SOME LEGENDS IN SAWAHLUNTO CITY}

\author{
Arriyanti \\ Balai Bahasa Sumatera Barat \\ arriyantiusman@gmail.com
}

\begin{abstract}
ABSTRAK
Tulisan ini mendeskripsikan dan mengkaji motif, fungsi, dan kearifan lokal beberapa legenda yang terdapat di Kota Sawahlunto. Penelitian ini merupakan penelitian kualitatif dengan menggunakan metode deksriptif komparatif. Untuk melihat motif cerita rakyat, penulis mengaplikasikan pengelompokan motif yang dirumuskan oleh Stith Thompson. Terdapat beberapa rumusan motif cerita rakyat, di antaranya 1) motif binatang, 2) motif tabu/pantangan, 3) motif penipuan, 4) motif masyarakat, 5) motif sifat/karakter, dan lain-lain. Fungsi sosial yang terungkap dalam pembahasan, di antaranya cerita rakyat yang berfungsi sebagai sarana untuk mendidik dan memberikan pelajaran tentang kehidupan, sarana mewariskan atau meneruskan tradisi suatu bangsa dalam arti yang positif, sarana untuk memberi sangsi sosial agar orang berperilaku baik atau memberi hukuman, sarana untuk memuji raja, pemimpin, orang-orang yang diangggap suci atau keramat, dan sebagainya. Nilai kearifan lokal yang terungkap di dalam cerita rakyat, di antaranya setiap kejahatan pasti mendapat hukuman, terdapat zat lain selain manusia, alam bisa menjadi sumber inspirasi penamaan suatu daerah, dan lain-lain.
\end{abstract}

Kata kunci: fungsi, legenda, motif, kearifan lokal.

\section{ABSTRACT}

This paper describes and examines about the motives, functions, and local wisdom of some legends in Sawahlunto. This research is a qualitative research using comparative descriptive method. To see the motives of folklore, the author applies a group of motives formulated by Stith Thompson. There are several formulas of folklore motives, among them 1) motives of animal, 2) motives of taboos, 3) motives of fraud, 4) motives of community, 5) motives of character, and others. The social functions revealed in the discussion, among others folklore that serves as a means to educate and learn about life, a means to inherit or continue the tradition of a nation in a positive sense, a means to give social sanctions for people to behave well or punish, the means to praise the kings, leaders, people who are considered as a holy one or sacred, and others. The value of local wisdom revealed in the folklore, among them any crime must be punished, there are substances other than humans, nature can be a source of inspiration to give a name to a region, and others.

Keywords: functions, legends, motives, local wisdom. 


\section{PENDAHULUAN}

Legenda sebagai salah satu bagian dari sastra lisan tumbuh dan berkembang di tengah masyarakat pemiliknya. Sebagai bagian dari suatu masyarakat sudah barang tentu, legenda mengungkap berbagai peristiwa atau kebudayaan masyarakat tersebut. Danandjaja (2002, h. 2) menyebutkan bahwa "folklor sebagai bagian kebudayaan suatu kolektif, yang tersebar dan diwariskan secara turun-temurun, di antara kolektif macam apa saja, secara tradisional dalam versi yang berbeda, baik dalam bentuk lisan maupun contoh yang disertai dengan gerak isyarat atau alat pembantu pengingat".

Folklor diciptakan oleh suatu masyarakat bukan hanya sebagai hiburan atau warisan budaya semata, tetapi folklor diciptakan berdasarkan motif-motif tertentu, sebagai pedoman atau petunjuk masyarakat pemiliknya. Hal tersebut dimungkinkan karena folklor mengandung nilai dan norma budaya. Nilai dan norma tersebutlah yang dimanfaatkan oleh masyarakat pemiliknya sebagai media untuk menata kehidupan mereka. Hal itu juga bertujuan untuk meningkatkan kesejahteraan dan menciptakan kedamaian masyarakat tersebut.

Masyarakat Minangkabau memiliki kekayaan sastra lisan yang sangat beragam. Mereka sudah mengakrabi sastra lisan tersebut dalam kurun waktu yang cukup panjang. Hal tersebut dimungkinkan karena masyarakat Minangkabau tidak memiliki tradisi menulis. Mereka lebih piawai dalam berbahasa. Kepiawaian dalam hal berbahasa tersebut, termasuk bersastra, menjadi hal yang mutlak bagi masyarakat Minangkabau. Oleh karena itu, setiap kelompok masyarakat, dengan kesatuan tertinggi adalah nagari, memiliki cerita rakyat yang tercipta, tumbuh, berkembang, dan saling memengaruhi antarnagari.

Perkembangan zaman tidak dapat dielakkan oleh masyarakat, khususnya generasi muda. Perkembangan tersebut bahkan cenderung mengikis kebudayaan yang dimiliki oleh masyarakat tertentu. Boleh dikatakan perkembangan zaman akan selalu membawa perubahan, baik perubahan yang bersifat posistif, maupun perubahan yang bersifat negatif. Perubahan yang bersifat posistif akan memberi manfaat kapada masyarakat, sebaliknya perubahan yang bersifat negatif akan mendatangkan dampak yang tidak baik terhadap manusia sebagai pencipta kebudayaan tersebut. Perubahan yang terjadi di berbagai bidang tersebut juga berakibat terhadap perubahan dan pergeseran fungsi pada sastra lisan. Oleh karena itu, masyarakat sebagai pemilik dari suatu kebudayaan harus lebih dewasa dalam mengahapi kondisi tersebut. Perubahan harus disikapi secara bijak oleh masyarakat. Jika disikapi secara tepat, perubahan akan mendatangkan kemajuan dalam kehidupan, termasuk dalam hal kebertahanan dan perkembangan sastra lisan. Sikap yang bijak dan tindakan yang tepat dalam menghadapi perubahan tersebut menjadikan sastra lisan tetap terjaga sebagai warisan budaya luhur yang memiliki kearifan lokal dan berfungsi bagi masyarakat pemiliknya.

Legenda sebagai bagian dari sastra lisan memiliki fungsi bagi masyarakat pemiliknya. Akan tetapi, seringkali fungsi tersebut tidak dipahami sebagai manifestasi oleh masyarakatnya. Padahal fungsi dapat membantu masyarakat dalam mewujudkan dan mengatur kehidupan sosial mereka. Selain itu, fungsi sastra lisan juga dapat digunakan sebagai alat untuk memahami masyarakat, serta menentukan 
perkembangan perilaku masyarakat yang berkepribadian dalam kehidupan sosialnya.

Sehubungan dengan hal itu, perlu suatu perhatian dan upaya dari para peneliti folklor dan peneliti kebudayaan dengan mengadakan penelitian untuk pengarsipan dan pendokumentasian. Hal tersebut bertujuan supaya legenda dan kebudayaan masyarakat pemiliknya tetap terjaga keberadaannya. Jika suatu legenda sebagai bagian dari sastra lisan mengalami perubahan atau penghilangan tentu akan berdampak pada masyarakat itu sendiri. Masyarakat pemilik akan kehilangan identitas sebagai masyarakat yang memiliki budaya tersebut. Karena sastra lisan menyimpan peristiwa, tingkah laku, dan adat istiadat yang dialami pemiliknya, yang terus-menerus dilakukan sehingga menjadi suatu kebudayaan. Kondisi tersebut mendorong peneliti untuk mengkaji motif, fungsi, dan kearifan lokal beberapa legenda di Kota Sawahlunto, Provinsi Sumatera Barat.

"Legenda adalah cerita rakyat yang bersifat keduniawian (sekular), mengisahkan masa lampau yang tidak begitu jauh, dan terjadi di dunia seperti yang kita kenal sekarang" (Danandjaja $(2002$, h. 66). Legenda juga diyakini sebagai kisah yang benar-benar pernah terjadi oleh masyarakat pendukungnya. Legenda bisa saja dianggap cerita suci atau cerita biasa yang bercerita tentang perpindahan penduduk, peperangan, kepahlawanan, raja dan para pemuka masyarakat, pergantian kepemimpinan dalam suatu kelompok etnik, serta berkaitan dengan asalusul penamaan suatu hal. Jan Harold Brunvand (dikutip di Danandjaya, 2002) menggolongkan "legenda menjadi empat kelompok, yaitu 1) legenda keagamaan (religious legend), 2) legenda alam gaib (supranatural legends), 3) legenda perseorangan (personal legends), dan 4) legenda setempat (local legends)".

Legenda biasanya mengandung nilai historis, seringkali dipandang sebagai "sejarah kolektif" (folk history) yang bercampur baur dengan mitos, bersifat migratoris (berpindah-pindah) hingga dikenal luas di beberapa daerah yang berbeda, dan seringkali pula tersebar dalam pengelompokan yang disebut siklus (cycle) atau sekelompok cerita yang berkisar pada suatu tokoh atau suatu kejadian tertentu.

Selanjutnya, motif adalah kata yang digunakan oleh para ahli folklor untuk menganalisis, menafsirkan, dan menjelaskan unsur-unsur tradisional yang ditemukan dalam adat istiadat, khususnya kelompok rakyat, dan membandingkan cerita rakyat berbagai daerah dan budaya dunia berdasarkan pola motif. Pada akhirnya, para ahli folklor mengidentifikasi motif dalam cerita rakyat untuk menafsirkan dimana, bagaimana, dan mengapa motif ini digunakan sehingga mereka dapat memahami nilai-nilai, kebiasaan, dan cara hidup budaya yang unik. Dalam antropologi budaya dan ilmu folklor, makna motif meliputi makna motif yang digunakan dalam bidang musik, kritik sastra, seni visual, dan seni tekstil.

Menurut Danandjaja (2002, h. 53-54), "istilah motif dalam ilmu folklor adalah unsur-unsur suatu cerita (narratines elements). Motif teks suatu cerita rakyat adalah unsur dari cerita itu yang menonjol dan tidak biasa sifatnya. Unsur-unsur itu dapat berupa benda (seperti tongkat wasiat), hewan luar biasa (kuda yang dapat bicara), suatu konsep (larangan atau tabu), suatu perbuatan (ujian ketangkasan), penipuan terhadap suatu tokoh (raksasa atau dewa), tipe orang tertentu (si Padir, si 
Kabayan), atau sifat struktur tertentu (misalnya penglangan berdasarkan angka keramat seperti angka tiga dan tujuh)".

Selanjutnya, di dalam cerita rakyat terdapat motif atau unsur-unsur cerita yang menonjol dan tidak biasa sifatnya. Pengelompokan motif dirumuskan oleh Stith Thompson (1955). Thompson merumuskan kelompok motif atau unsur-unsur suatu cerita (narratives elements) itu tersebut sebagai berikut. 1) Motif binatang, 2) Motif tabu/pantangan, 3)Motif sihir, 4) Motif kematian, 5) Motif keajaiban, 6) Motif raksasa, 7)Motif ujian, 8) Motif kebijaksanaan dan kebodohan, 9) Motif penipuan, 10) Motif pembalikan keberuntungan/nasib, 11) Motif menasbihkan masa depan, 12) Motif kebetulan dan nasib, 13) Motif masyarakat, 14) Motif hadiah dan hukuman, 15) Motif tawanan dan buronan, 16)m Motif kekejaman/kebiadaban, 17) Motif sex, 18) Motif sifat hidup, 19) Motif kepercayaan, 20) Motif sifat/karakter, 21) Motif humor, 22) Motif lain-lain.

Cerita rakyat, sebagai salah satu folklor lisan, mempunyai fungsi-fungsi yang menjadikannya penting dan sangat menarik untuk diselidiki. Fungsi-fungsi yang dimaksud merupakan bagian dari suatu kebudayaan yang terdapat kehidupan sosial masyarakat. Jadi, cerita rakyat memiliki fungsi-fungsi sosial yang merupakan realitas kehidupan dan bermanfaat sebagai alat untuk mengendalikan kehidupan sosial suatu masyarakat.

Semi (1984, h. 10-14) membagi "fungsi sosial cerita rakyat ke dalam empat fungsi sosial, yaitu: (1) menghibur adalah suatu karya sastra yang diciptakan berdasarkan keinginan melahirkan suatu rangkaian berbahasa yang indah dan bunyi yang merdu saja, (2) mendidik adalah suatu karya sastra yang dapat memberikan pelajaran tentang kehidupan, karena sastra mengekspresikan nilai-nilai kemanusiaan seperti yang terdapat dalam agama. Nilai-nilai yang disampaikannya dapat lebih fleksibel. Di dalam sebuah karya sastra yang baik kita akan menemui unsur-unsur dari ilmu filsafat, ilmu kemasyarakatan, (3) mewariskan adalah suatu karya sastra yang dijadikan alat untuk meneruskan tradisi suatu bangsa dalam arti yang positif. Tradisi itu memerlukan alat untuk meneruskannya kepada masyarakat sezaman dan masyarakat yang akan datang, (4) jati diri adalah suatu karya sastra yang menjadikan dirinya sebagai suatu tempat di mana nilai kemanusiaan mendapat tempat yang sewajarnya, dipertahankan, dan disebarluaskan, terutama di tengahtengah kehidupan modern yang ditandai dengan menggebu-gebunya kemajuan sains dan teknologi".

Sejalan dengan hal tersebut, Dundes (dikutid di Sudikan, 2001, h. 162) menyatakan "ada beberapa fungsi sosial cerita rakyat secara umum, yaitu: (a) membantu pendidikan anak muda, (b) meningkatkan perasaan solidaritas suatu kelompok, (c) memberi sangsi sosial agar orang berperilaku baik atau memberi hukuman, (d) sebagai sarana kritik sosial, (e) memberikan suatu pelarian yang menyenangkan dari kenyataan, dan (f) mengubah pekerjaan yang membosankan menjadi permainan". Lain halnya dengan pendapat Hamidy (2003, h. 28), menyatakan bahwa "fungsi sosial cerita rakyat di antaranya sarana pendidikan, harga diri, dan sebagai hiburan atau pelipur lara".

Selanjutnya, Atmazaki (2007, h. 138) mengemukakan bahwa "fungsi sosial sastra lisan meliputi: (1) untuk mengekspresikan gejolak jiwa dan renungannya tentang kehidupan oleh masyarakat purba atau nenek moyang kita dahulu, (2) untuk 
mengukuhkan solidaritas dan menyegarkan pikiran dan perasaan, (3) digunakan untuk memuji raja, pemimpin, dan orang-orang yang diangggap suci, keramat, dan berwibawa oleh kolektifnya. Bascom dalam (Pudentia, 2008:73) menyatakan bahwa gungsi sosial sastra lisan tersebut ada empat: (1) sebagai sistem proyeksi, (2) sebagai alat pengesahan kebudayaan, (3) sebagai alat pedagogik, dan (4) sebagai alat pemaksa berlakunya norma masyarakat dan pengendalian masyarakat)".

Jadi, berdasarkan pendapat-pendapat di atas dapat disimpulkan bahwa banyak fungsi sosial cerita rakyat, di antaranya; (1) sebagai sarana hiburan, (2) sebagai sarana pendidikan (3) alat kontrol sosial, (4) pengukuhan solidaritas sosial, (5) identitas kelompok, (6) harmonisasi komunal, (7) pengesahan kebudayaan, dan (8) digunakan sebagai pemujian terhadap raja, pemimpin, dan orang-orang yang dianggap suci, keramat, dan berwibawa oleh kolektifnya.

Pengertian kearifan lokal (local wisdom) dalam kamus terdiri dari dua kata: kearifan (wisdom) dan lokal (local). Echols dan Shadily (2005, h. 319\&649), local berarti setempat, sedangkan wisdom (kearifan) sama dengan kebijaksanaan. Secara umum,local wisdom (kearifan setempat) dapat dipahami sebagai gagasan-gagasan setempat (local) yang bersifat bijaksana, penuh kearifan, bernilai baik, serta yang tertanam dan diikuti oleh anggota masyarakatnya. Dalam disiplin antropologi dikenal istilah local genius.

Gobyah (2003, h. 13) mengatakan bahwa "kearifan lokal (local genius) adalah kebenaran yang telah mentradisi atau ajeg dalam suatu daerah. Kearifan lokal merupakan perpaduan antara nilai-nilai suci firman Tuhan dan berbagai nilai yang ada. Kearifan lokal terbentuk sebagai keunggulan budaya masyarakat setempat maupun kondisi geografis dalam arti luas. Kearifan lokal merupakan produk budaya masa lalu yang patut secara terus-menerus dijadikan pegangan hidup. Meskipun bernilai local, tetapi nilai yang terkandung didalamnya dianggap sangat universal".

Menurut Caroline Nyamai-Kisia (2012), "kearifan lokal adalah sumber pengetahuan yang diselenggarakan dinamis, berkembang dan diteruskan oleh populasi tertentu yang terintegrasi dengan pemahaman mereka terhadap alam dan budaya sekitarnya. Kearifan lokal adalah dasar untuk pengambilan kebijakan pada level lokal di bidang kesehatan, pertanian, pendidikan, pengelolaan sumber daya alam dan kegiatan masyarakat pedesaan. Dalam kearifan lokal, terkandung pula kearifan budaya lokal. Kearifan budaya lokal sendiri adalah pengetahuan lokal yang sudah sedemikian menyatu dengan sistem kepercayaan, norma, dan budaya serta diekspresikan dalam tradisi dan mitos yang dianut dalam jangka waktu yang lama".

Nilai budaya merupakan bagian dari kearifan lokal atau di dalam kearifan lokal terdapat nilai-nilai budaya. Nilai budaya, menurut Koentjaraningrat (2000, h. 85), terdiri atas "konsepsi-konsepsi yang hidup dalam pikiran sebagian besar warga masyarakat mengenai hal-hal yang mereka anggap mulia. Sistem nilai yang ada dalam suatu masyarakat dijadikan orientasi atau rujukan dalam bertindak. Oleh sebab itu, nilai budaya yang dimiliki seseorang memengaruhi perilaku hubungan dengan alam, hubungan sesama manusia, dan tentang hal-hal yang diingininya dalam kehidupan di dunia". 


\section{METODE}

Penelitian ini adalah penelitian lapangan (field research) dan penelitian kepustakaan (library research). Penelitian ini merupakan penelitian kualitatif dengan menggunakan metode deksriptif komparatif. Menurut Endaswara (dikutip di Gayatri, 2008, h. 3), "penggunaan metode kualitatif dalam penelitian cerita rakyat disebabkan oleh kenyataan bahwa cerita rakyat mengandung unsur-unsur budaya yang diamanatkan pendukung budaya tersebut. Artinya, peneliti tidak hanya menitikberatkan perhatian pada unsur folk saja, namun juga unsur lore-nya. Kedua unsur tersebut saling berkaitan, sekaligus membentuk sebuah komunitas budaya yang unik".

"Penelitian folklor terdiri atas tiga tahap, yaitu pengumpulan, penggolongan (pengklasifikasian), dan penganalisisan. Penelitian yang bertujuan untuk pendokumentasian atau pengarsipan bersifat penelitian di tempat (field work). Ada tiga tahap yang harus dilalui oleh peneliti, yaitu tahap 1) prapenelitian di tempat, 2) penelitian di tempat yang sesungguhnya, dan 3) cara pembuatan naskah untuk pengarsipan. Selanjutnya dilanjutnya dengan klasifikasi” (Danandjaja, 2002, h. 185).

Ben Amos (dikutip di Endaswara, 2009, h. 106) tergolong ahli folklor yang banyak memberikan rumusan klasifikasi teori. "Dia mengklasifikasikan folklor berupa kisah dengan sebutan mite, legenda, dan dongeng atas cerita. Klasifikasi genre tersebut dapat dilihat dari 1) kategori klasifikasi, 2) bentuk permanen, 3) bentuk terlibat, dan 4) bentuk wacana. Berdasarkan uraian tersebut, penelitian ini memakai konsep pertama, yaitu kategori klasifikasi.. Kategori klasifikasi adalah klasifikasi yang didasarkan pada kategori tertentu, misalnya dari segi tema atau latar belakangnya".

Adapun teknik yang dilakukan peneliti guna lancarnya penelitian ini adalah melalui observasi, wawancara, perekaman, pencatatan, pengklasifikasian, dan analisis.

\section{ANALISIS DAN PEMBAHASAN}

Pada bagian ini akan dibahas motif, fungsi, dan kearifan lokal beberapa legenda Minangkabau di Kota Sawahlunto, Provinsi Sumatera Barat.

\section{Legenda Lubuak Sipotang}

Lubuak Sipotang adalah nama daerah yang terdapat di dusun Batu Tajam, desa Kubang Tangah, negeri Kubang. Di sekitar daerah Lubuak Sipotang dikelilingi hutan rimba. Mengapa bernama Lubuak Sipotang? Hal itu terjadi karena daerah tersebut terlihat seperti sore hari dan tidak disinari matahari dari pagi sampai sore hari. Situasi di Lubuak Sipotang sangat menyeramkan karena daerah tersebut agak gelap. Ternyata, daerah Lubuak Sipotang terkenal angker. Daerah itu merupakan tempat hantu Singeak-ngeak yang diyakini oleh masyarakat setempat sebagai hantu yang berbunyi atau bersuara seperti tangisan bayi.

Jadi, ada dua orang penduduk yang tinggal di Batu Tajam. Suatu hari mereka pergi bermain ke Sikabu. Setelah hari sore dan tidak disinari matahari, mereka berjalan dari Sikabu melewati Lubuak Sipotang menuju dusun Batu Tajam. Karena asik bercerita, hari mulai malam dan sepi, bahkan lampu pun tidak ada. Kedua orang itu hanya memakai obor untuk menerangi perjalanan mereka. Selama dalam 
perjalanan, walaupun sambil bercerita, mereka juga merasakan sesuatu yang aneh dan membuat mereka merinding. Selanjutnya, dari kejauhan mereka melihat orang ramai berjalan dan ada yang mengusung tandu sambil berbicara.

Melihat orang ramai itu, akhirnya, senanglah hati kedua pemuda tersebut. Mereka merasa tidak takut lagi melewati daerah Lubauk Sipotang itu. Akan tetapi, mereka juga merasa heran karena tandu yang diusungnya itu terdengar suara anak menangis. Tandu yang diusung oleh orang tersebut berbunyi seperti "kicik....kicik...kicik...ngeak-ngeak...kicik...kicik...kicik...ngeak-ngeak..." Kedua pemuda tadi melihat saja rombongan itu berjalan. Setelah hampir mendekati, rombongan tersebut tiba-tiba hilang. Terkejutlah kedua pemuda itu sambil mengucap ayat alquran. Semenjak kejadian itu, tersebarlah berita bahwa di Lubuak Sipotang itu ada hantu Singeak-ngeak (hantu menangis).

\section{Motif Legenda Lubuak Sipotang}

Cerita "Lubuak Sipotang" ini dapat digolongkan ke dalam legenda alam gaib. Legenda alam gaib bisanya berbentuk kisah yang dianggap benar-benar terjadi dan pernah dialami seseorang. Fungsi legenda semacam ini adalah untuk meneguhkan kebenaran tahayul atau kepercayaan rakyat.

\section{Sekuen}

a. Terdapat daerah yang dikelilingi rimba.

b. Daerah tersebut terlihat menyeramkan karena tidak tertembus sinar matahari.

c. Dua orang penduduk melintasi daerah itu pada sore hari.

d. Mereka kemalaman dan melihat serombongan orang yang mengusung tandu.

e. Dari arah tandu terdengar suara seperti orang menangis.

\section{Motif}

a. C40: Tabu terkait dengan roh air, gunung, dan lain-lain (hantu si ngeak-ngeak/ hantu menangis).

b. C610: Satu tempat terlarang (Karena angker, orang tidak berani mendekati tempat itu).

c. E200-E599: Hantu dan arwah lainnya (hantu singeak-ngeak).

\section{Fungsi Legenda Lubuak Sipotang}

"Legenda Lubuak Sipotang" mengangkat kisah mengenai sebuah tempat yang dianggap dihuni oleh makhluk gaib. Hal itu dipercaya oleh masyarakat berdasarkan pengalaman dua orang penduduk yang mengaku bertemu dengan makhluk gaib di tempat tersebut. Kisah ini berfungsi sebagai sarana pendidikan dan memberikan pelajaran tentang kehidupan, khususnya agama.

\section{Kearifan Lokal Legenda Lubuak Sipotang}

Legenda 'Lubuak Sipotang' mengisahkan tentang daerah yang diyakini dihuni oleh makhluk gaib. Kearifan lokal yang terdapat dalam kisah tersebut adalah bahwa terdapat zat lain selain manusia, ada makhluk lain yang juga menjadi makhluk ciptaan Allah. Dialah jin yang diciptakan oleh Allah untuk menguji keimanan manusia. Selain itu, kearifan lokal yang bisa dipetik dari kisah ini adalah 
bahwa ketika memasuki suatu daerah baru, kita harus bisa menyesuaikan diri dengan lingkungan yang baru tersebut. Apalagi daerah tersebut merupakan rimba raya yang belum terjamah oleh manusia.

\section{Legenda Puncak Sugai/Puncak Polan dan Batang Sumpahan}

Cerita Batu si Anjiang Jatuah berhubungan erat dengan cerita Bukit Sugai/Puncak Polan dan Batang Sumpahan. Alasan dinamai Bukik Sugai karena pemuda tersebut berteriak sekuat tenaga sampai keluar urat di dahinya karena memanggil si anjing ketika si pemuda itu berada di bukit tersebut. Selanjutnya, galah bambu yang dibawa oleh pemuda tersebut ditancapkannya di puncak tersebut. Kemudian, galah bambu tersebut tumbuh dan berkembang di atas bukit Sugai itu.

Pemuda Kubang yang menyumpahi anjing kesayangannya yang tidak mau mendengar panggilannya melakukan sumpah di sekitar aliran sungai sehingga sungai itu disebut dengan batang Sumpahan. Batang Sumpahan itu sekarang terletak di Desa Kubang, Sirakuk Utara Sikabu. Batas batang Sumpahan bermuara di batang Lunto dekat museum tambang. Bagian ilirnya Sikabu dan berhulu di Sumpahan, di Simpang Sikabu, dan Lubang Panjang.

\section{Motif Legenda Puncak Sugai/Puncak Polan dan Batang Sumpahan}

Legenda Puncak Sugai dan Batang Sumpahan" dapat dikelompokkan ke dalam legenda setempat. Legenda setempat adalah legenda yang berhubungan dengan tempat, nama tempat, atau bentuk topografi suatu daerah. Legenda ini masih berkaitan erat dengan legenda "Batu si Anjiang Jatuah" karena tokoh yang muncul di dalamnya masih melibatkan tokoh di dalah kisah "Batu si Anjiang Jatuah".

Puncak Sugai merupakan penamaan dari orang Kubang pertama. Sesudah itu, Puncak Sugai berubah nama menjadi Puncak Polan. Orang Kubang menamakannya Puncak Sugai dan orang Sawahlunto menamakannya Puncak Polan. Alasan dinamakan Puncak Polan karena ada orang Polandia yang melakukan survei tambang pada zaman dahulu (sekitar tahun 1960-1970). Orang Polandia itu meninggal dan dikuburkan di tempat itu.

\section{Sekuen}

a. Seorang pemuda mencari anjingnya yang hilang.

b. Ia berteriak sekuat tenaga memanggil anjingnya di atas sebuah bukit.

c. Si pemuda marah karena si anjing tidak kunjung tiba.

d. Ia menyumpahi anjing itu di sekitar aliran sungai hingga menjadi batu.

\section{Motif}

a. A930: Asal sungai (Asal Batang Sumpahan).

b. A980: Asal tempat tertentu (Asal Puncak Sugai).

c. M100: Sumpah dan janji (si pemuda menyumpahi anjingnya).

\section{Fungsi Legenda Puncak Sugai/Puncak Polan dan Batang Sumpahan}

"Legenda Puncak Sugai dan Batang Sumpahan" berhubungan erat dengan kisah "Batu si Anjiang Jatuah". Ketika berteriak memanggil si anjing yang tidak 
mau patuh dengan perintahnya, majikan anjing tersebut sedang berada di sebuah bukit. Sementara itu, sumpah yang diucapkan oleh majikan si anjing yang berakibat si anjing menjadi batu diucapkan di sekitar aliran sungai yang kemudian dikenal dengan batang Sumpahan. Fungsi sosial cerita ini berupa pemberian sangsi dan hukuman terhadap siapa saja yang melakukan tindakan tidak terpuji. Sangsi sosial tersebut diberikan untuk memberikan efek jera kepada yang bersangkutan.

\section{Kearifan Lokal Legenda Puncak Sugai/Puncak Polan dan Batang Sumpahan}

Kearifan lokal yang dapat dipetik dari 'Legenda Puncak Sugai" adalah bahwa setiap kejahatan pasti mendapat hukuman. Hukuman tersebut bertujuan untuk memberikan efek jera bagi mereka yang melakukan tindakan kejahatan. Oleh sebab itu, jauhilah tindakan kejahatan karena akan mendatangkan kerugian, baik bagi orang yang bersangkutan maupun bagi orang lain.

\section{Asal-Usul Nagari Kajai}

Tersebutlah datuak kepala kaum yang bergelar Datuak Rajo Lelo. Ia memelihara tiga ekor kuda yang selalu lepas dari ikatannya ketika pergi minum menuju anak air di muka sebuah gua. Alkisah pada suatu hari, kuda berontak, kemudian lari menuju anak air. Melihat keadaan seperti itu, datuak kapalo kaum mengikuti sampai di lereng bukit. Karena lari kudanya sangat kencang, seekor kuda jatuh ke bawah jalan. Datuak kapalo kaum sangatlah marah dan menyumpah seketika itu juga. Karena Tuha Maha Kuasa, kuda yang jatuh itu pun menjadi batu. Sampai kini di tempat itu dinamakan Batu Kudo Tagolek.

Kuda yang dua ekor lagi terus berlari sehingga hilang dari pandangan. Karena keadaan yang seperti itu, dipanggillah orang banyak. Kuda yang dua ekor lagi itu 'dikajai' (dikejari). Karena lama di jalan, sampailah di depan sebuah gua. Datuak Sutan Dilangik dengan Khatib Rajo mendapati kuda sedang minum. Kemudian, dipanggillah pemilik kuda itu. Datuak Rajo Lelo pun tiba. Melihat kuda sedang minum, dipanggil dengan nada tinggi. Seekor kuda lari ke atas, sedangkan yang seekor lagi, yaitu induk kuda hanya tegak berdiri. Ia sekadar melengong ke belakang. Pada saat itu manjadi batulah kuda itu sehingga dinamakan Batu Kudo.

Kuda yang lari ke atas, sampai di bukit batu. Ketika sampai di tempat itu, dengan kekuasaan Tuhan, kuda itu pun menjadi batu. Dinamailah daerah tersebut dengan Batu Tangah. Ketika dilihat daerah sekitar gua, daerah itu patut menjadi tempat tinggal. Mungkin untuk meneroka sawah dan ladang. Akhirnya, dibawalah anak dan kemenakan pindah ke daerah baru. Dinamailah daerah koto tersebut dengan Koto Tingga.

Ketika negeri akan dibangun, mereka belum mempunyai balai dan mesjid. Maka di-kaja-i untuk bermusyawarah. Artinya, tanpa persiapan yang memadai, diundanglah Datuak nan Sambilan dari lima negeri. Dua orang datuk dari Kubang, dua dari Kolok, dua dari Lunto, dua dari Simarambang, serta satu orang datuak dari Kajai sebagai yang dituakan. Musyawarah itu diadakan di Balerong Batu Sandaran yang sampai saat ini masih berdiri. Setelah selesai bermusyawarah, sepakatlah semua datuak dan menetapkan nama nagari itu sebagai nagari Kajai. 


\section{Motif Asal-Usul Nagari Kajai}

Kisah "Asal-Usul Nagari Kajai" dapat dikelompokkan ke dalam bentuk legenda setempat. Legenda setempat adalah legenda yang berhubungan dengan tempat, nama tempat, dan bentuk topografi suatu daerah.

\section{Sekuen}

a. Seorang datuk memelihara tiga ekor kuda.

b. Kuda-kuda itu selalu lepas dari ikatannya katika pergi minum.

c. Seekor kuda berhasil melepaskan diri dari tali ikatannya.

d. Datuk marah dan mengutuknya hingga menjadi batu.

e. Dua ekor kuda juga berhasil lepas dari ikatannya.

f. Datuk mengejar kuda-kuda itu dibantu oleh penduduk lainnya.

g. Kuda-kuda itu tidak mau berhenti.

h. Datuk marah dan mengutuk mereka hingga menjadi batu.

\section{Motif}

a. M400: Kutukan (Datuk mengutuk ketiga ekor kudanya hingga menjadi batu).

b. Q550: Hukuman ajaib (Kuda dihukum hingga menjadi batu).

\section{Fungsi Asal-Usul Nagari Kajai}

"Kisah Asal-Usul Nagari Kajai" ini menceritakan tentang asal-usul penamaan nagari Kajai. Fungsi sosial kisah ini berupa pewarisan suatu tradisi dan menjadikan tradisi tersebut sebagai sesuatu yang bernilai posistif. Tradisi tersebut memerlukan suatu alat untuk meneruskannya kepada masyarakat sezaman atau meneruskannya kepada masyarakat yang akan datang. Selain itu, kisah ini juga memiliki fungsi sebagai sarana pendidikan bagi generasi muda untuk dapat memperbaiki diri agar menjadi orang yang lebih baik. Selanjutnya, kisah ini juga berfungsi untuk memberikan sangsi sosial dan hukuman yang diterima jika melakukan perbuatan yang tidak baik.

\section{Kearifan Lokal Asal-Usul Nagari Kajai}

Kearifan lokal yang dapat dipetik dari kisah "Asal-Usul Nagari Kajai” adalah bahwa kesetiaan sangat penting di dalam kehidupan. Orang yang setia akan mendapat penghargaan dari orang lain. Sebaliknya, mereka yang tidak setia akan mendapat ganjaran dari ketidaksetiaan mereka itu. Hal itu terlihat di dalam kisah ini. Kuda yang tidak setia dan patuh pada majikannya, akhirnya mendapat hukuman secara gaib. Kuda yang tidak mau menurut perintah majikannya itu pun mengalami hukuman dan dikutuk oleh majikannya hingga menjadi batu.

\section{Legenda Lubuak Antuan}

Menurut penuturan seorang warga tentang Lubuak Antuan, dulu semasa kecil dia sering main dan berenang dengan meloncat indah di atas bebatuan Lubuak Antuan. Warga di sekitar desa Kubang Tangah banyak yang mengatakan bahwa di Lubuak Antuan itu banyak hantu dan ada air terjun yang di bawahnya membentuk sebuah cekungan dalam yang dipenuhi air. Ketika itu terdengar bunyi air yang sangat bising dan mengganggu para penduduk yang sedang berladang. Sehingga 
pada suatu hari ada seorang laki-laki yang memiliki ladang di sekitar Lubuak Antuan tersebut mengungkit sebuah batu besar yang dianggapnya menghambat jalur air yang berasal dari air terjun tersebut. Akhirnya, batu besar tersebut berhasil disingkirkan oleh laki-laki itu. Namun, keesokan harinya si laki-laki sakit tanpa diketahui apa penyebabnya sampai akhirnya beliau meninggal. Menurut warga setempat, kemungkinan si laki-laki itu disakiti oleh penghuni Lubauk Antuan tersebut karena telah membuang batu yang ada di lubuak itu.

Semenjak batu dibuang oleh laki-laki itu, bunyi suara bising itu hilang sehingga setiap warga merasa nyaman katika melewati daerah itu.

\section{Motif Legenda Lubuak Antuan}

Kisah "Lubuak Antuan" dapat dikelompokkan ke dalam bentuk legenda setempat. Legenda setempat adalah legenda yang berhubungan dengan tempat, nama tempat, dan bentuk topografi suatu daerah. Kisah ini berkembang di tengah masyarakat Kubang.

\section{Sekuen}

a. Terdapat sebuah lubuk yang diyakini warga ada hantunya.

b. Dari lubuk itu selalu terdengar suara air yang sangat bising hingga mengganggu warga yang sedang berladang.

c. Seorang warga mengungkit sebuah batu besar yang dianggap sebagai penyebab suara bising itu.

d. Batu berhasil diangkat dan suara bising pun hilang

e. Setelah mengungkit batu, laki-laki itu jatuh sakit hingga akhirnya meninggal.

f. Warga percaya bahwa laki-laki itu disakiti oleh penghuni lubuk karena telah membuang batu.

\section{Motif}

a. C40: Tabu berkaitan dengan roh air, gunung (lubuk yang diyakini ada penghuninya).

b. C610: Satu tempat terlarang (Lubuk Antuan jarang didatangi orang).

c. C900: Hukuman bagi pelanggar tabu (seorang penduduk meninggal karena mengangkat batu dari lubuk).

d. C920: Kematian karena melanggar tabu (seorang penduduk meninggal karena sakit setelah membuang batu dari lubuk).

e. C940: Penyakit atau kelemahan karena melanggar tabu (seorang penduduk jatuh sakit setelah membuang batu dari lubuk).

f. E400: Hantu dan arwah lainnya (hantu di sebuah lubuk).

\section{Fungsi Legenda Lubuak Antuan}

"Lubuak Antuan" menceritakan tentang sebuah tempat yang dianggap keramat dan dihuni oleh makhluk halus. Setiap orang yang berusaha mendatangi atau mengusik tempat tersebut akan mendapatkan hukumannya. Ia akan jadi sakit dan akhirnya meninggal. Fungsi sosial kisah ini berupa pewarisan suatu tradisi dalam arti positif. Selain itu, kisah ini juga berfungsi sebagai perenungan mengenai kehidupan nenek moyang kita dahulu. 


\section{Kearifan Lokal Legenda Lubuak Antuan}

Kearifan lokal yang terdapat di dalam cerita "Lubuak Antuan" adalah terdapat kehidupan lain di dunia ini selain kehidupan manusia. Ada alam lain dengan makhluk yang mendiaminya. Ada alam nyata dan juga ada alam gaib. Masyarakat percaya bahwa selain manusia ada makhluk lain ciptaan Allah yang mendiami tempat-tempat tertentu di alam ini. Terkadang mereka menunjukkan keberadaannya kepada manusia. Oleh sebab itu, manusia harus lebih arif dan bijaksana dalam menghadapi fenomena ini.

\section{Legenda Lasuang Manangih}

Tersebutlah pada masa dahulu kala, tatkala nagari Lumindai masih muda umurnya. Pada suatu ketika, sekelompok ninik mamak orang Lumindai berjalanjalan ke puncak sebuah bukit yang terdapat di nagari Lumindai. Konon kabarnya dari puncak bukit tersebut kita dapat memandang lepas ke berbagai penjuru. Danau Singkarak dapat terlihat jelas dari atas bukit tersebut, begitu juga berbagai nagari yang jauh, yang masih berupa rimba raya.

Maka terbersitlah keinginan dari beberapa orang ninik mamak untuk meneroka rimba raya tersebut untuk dijadikan sebuah nagari. Dari atas puncak bukit tersebutlah dimulai langkah oleh beberapa orang ninik mamak guna mencari lahan baru. Dibawa serta rombongan anak kemenakan untuk mendiami negeri baru tersebut.

Dari atas puncak bukit tersebut, ninik mamak tersebut turun menuju nagari yang sekarang kita kenal dengan nama Solok, Guguak Sarai, Pulau Punjuang, dan beberapa nagari lainnya. Kepergian ninik-ninik ini berserta rombongan dilepas oleh ninik-ninik yang lain beserta anak nagari Lumindai lainnya. Ketika melepas rombongan yang hendak pergi itu, mereka semua saling bertangisan karena mengingat entah kapan akan bertemu lagi.

Dinamailah puncak bukit itu dengan nama Lasuang Manangih karena di atas puncak tersebut terdapat sebuah lesung yang konon kabarnya selalu mengeluarkan air ibarat orang menangis. Walau telah dikeluarkan air hingga kering, lesung tersebut pasti akan kembali mengeluarkan air.

Lasuang Manangih adalah lesung keramat karena apabila dipindahkan dari tempatnya, lesung ini dengan sendirinya akan kembali ke tempatnya semula. Begitu juga dengan cerita lainnya, pernah ada yang melihat Lasuang Manangih ini berkelahi dengan batu Taboliak di batang Lunto.

\section{Motif Legenda Lasuang Manangih}

Cerita "Lasuang Manangih" dapat dikelompokkan ke dalam legenda setempat. Legenda setempat adalah legenda yang berhubungan dengan tempat, nama tempat, dan bentuk topografi suatu daerah. Legenda ini berkembang di tengah masyarakat nagari Lumindai.

\section{Sekuen}

a. Sekelompok ninik mamak mencari daerah baru untuk dihuni.

b. Di tempat itu, mereka mendapati sebuah lesung.

c. Lesung itu selalu basah dan mengeluarkan air. 
d. Setiap kali dilap, lesung itu kembali mengeluarkan air.

e. Lesung itu dianggap keramat karena jika dipindahkan lesung itu akan kembali lagi ke tampatnya.

\section{Motif}

F800: Batu dan bebatuan luar biasa (Lesung yang selalu mengeluarkan air).

\section{Fungsi Legenda Lasuang Manangih}

"Lasuang Manangih" mengisahkan tentang sebuah lesung yang selalu mengeluarkan air layaknya orang menangis.Walaupun sudah dikeluarkan airnya hingga kering, lesung tersebut pasti akan kembali mengeluarkan air. Fungsi sosial kisah ini berupa pewarisan terhadap suatu tradisi yang dianggap positif oleh masyarakat pendukungnya. Selain itu, kisah ini juga berfungsi sebagai sarana pendidikan agar generasi muda bisa memetik hal-hal yang positif dan membuang jauh-jauh efek negatif dari kisah ini.

\section{Kearifan Lokal Legenda Lasuang Manangih}

Nilai kearifan lokal yang dapat dipetik dari kisah "Lasuang Manangih" adalah terdapat kepercayaan terhadap hal-hal yang bersifat gaib. Hal-hal yang bersifat gaib itu didukung oleh kenyataan yang terlihat oleh masyarakat sehingga sebagian besar dari mereka mempercayai hal tersebut.

\section{Legenda Puncak Panjaringan}

Puncak Panjaringan adalah nama sebuah puncak bukit yang ada di nagari Lumindai. Puncak ini merupakan puncak tertinggi di mana dari puncak ini danau Singkarak dan gunung Merapi dapat terlihat dengan jelas. Tersebutlah pada masa dahulu, tatkala nagari Lumindai masih muda umurnya, sekelompok ninik mamak dari gunung Merapi dengan ninik mamak dari nagari Lumindai bermufakat untuk merentangkan jaring dari gunung Merapi hingga mencapai ke puncak salah satu bukit di nagari Lumindai. Kelak puncak tersebut dikenal dengan nama Puncak Panjaringan.

Terdapat beragam tafsir dari kisah ini pada penduduk nagari Lumindai. Ada yang berpandangan bahwa jaring yang dimaksud bukanlah jaring yang biasa dipakai orang untuk menangkap ikan, melainkan jaringan para pemuka adat dari gunung Merapi dan nagari Lumindai. Demikianlah kenapa puncak tersebut bernama Puncak Panjaringan.

\section{Motif Legenda Puncak Panjaringan}

Cerita "Puncak Panjaringan" dapat dikelompokkan ke dalam legenda setempat. Legenda setempat adalah legenda yang berhubungan dengan tempat, nama tempat, dan bentuk topografi suatu daerah. Legenda ini berkembang di tengah masyarakat nagari Lumindai. 


\section{Sekuen}

a. Sekelompok ninik mamak bermufakat.

b. Mereka akan merentangkan jaring dari gunung Merapi hingga mencapai puncak salah satu bukit.

c. Bukit itu dinamai Puncak Panjaringan.

\section{Motif}

a. F600: Orang dengan kekuatan luar biasa (Orang dapat merentangkan jaring dari gunung Singgalang ke puncak bukit).

b. F700: Tempat luar biasa (Gunung dan bukit yang dihubungkan dengan sebuah jaring yang dibentangkan di antara keduanya).

\section{Fungsi Legenda Puncak Panjaringan}

"Legenda Puncak Panjaringan" mengisahkan tentang beberapa datuk dari nagari Lumindai dan lereng gunung Merapi merentangkan jaring dari gunung Merapi hingga mencapai puncak salah satu bukit di daerah tersebut. Kisah ini berfungsi sebagai sarana untuk memuji raja, pimpinan, dan orang-orang yang dianggap suci, keramat, dan berwibawa oleh masyarakatnya. Selain itu, kisah ini juga berfungsi sebagai saranan pendidikan bagi generasi penerus agar mereka bisa mengambil hikmah dari kisah yang ada. Kisah ini bermanfaat bagi mereka untuk menjalani kehidupan yang lebih baik.

\section{Kearifan Lokal Legenda Puncak Panjaringan}

Nilai kearifan lokal yang dapat dipetik dari kisah "Puncak Panjaringan" adalah bahwa kepercayaan terhadap tokoh-tokoh masyarakat yang dianggap bertuah dan memiliki kesaktian berkembang di tengah masyarakat. Mereka mengagung-agungkan dan menghormati tokoh-tokoh tersebut. Keberadaan mereka di tengah masyarakat dianggap penting dan menjadi bagian yang tidak bisa dilepaskan dari kehidupan mereka.

\section{Legenda Titah Datuak Batuah}

Sungai Tarab, sebuah nagari di kaki gunung Merapi mengalami sebuah musibah. Di daerah itu hidup seekor ular naga yang sangat besar. Naga itu sering memakan hewan ternak masyarakat. Tidak hanya hewan ternak, sang naga ini juga sering memangsa masyarakat yang mencari kayu ke hutan. Mendengar kesaktian si orang tua (Titah Datuak Batuah), tetua dari daerah Sungai Tarab mendatangi si orang tua untuk meminta si orang tua agar membunuh naga yang ada di daerahnya. Tetua Sungai Tarab menawarkan kepada si orang tua apabila si orang tua berhasil membunuh sang naga, si orang tua akan diberikan imbalan tanah di daerah Sungai Tarab tersebut. Si orang tua karena memiliki kesaktian yang cukup tinggi dengan mudah berhasil membunuh sang naga. Tetua Sungai Tarab memberikan sebidang tanah kepada Titah Datuak Batuah sebagai imbalannya. Daerah ini kemudian diberi nama desa Mindai. Sampai ajal menjemput, si orang tua tinggal di desa Mindai dan jenazahnya dimakamkan di daerah tersebut. Hubungan kekerabatan antara masyarakat nagari Lumindai dengan masyarakat desa Mindai di nagari Sungai Tarab, Kabupaten Tanah Datar sampai sekarang masih terjalin dengan baik. 
Apabila ada masyarakat Lumindai yang ingin berkebun dan berladang di daerah desa Mindai, dengan senang hati masyarakat desa Mindai akan memberikan sebidang tanah untuk diolah menjadi ladang dan kebun.

\section{Motif Legenda Titah Datuak Batuah}

Cerita "Titah Datuak Batuah" dapat dikelompokkan ke dalam legenda alam gaib. Legenda alam gaib biasanya berbentuk kisah yang dianggap benar-benar terjadi dan pernah dialami oleh seseorang. Walaupun merupakan pengalaman pribadi seseorang, isi pengalaman itu mengandung banyak motif cerita tradisional yang khas di dalam masyarakat. Kisah ini berkembang di tengah masyarakat nagari Lumindai.

\section{Sekuen}

a. Terdapat seekor naga yang sering mengganggu penduduk.

b. Seorang penghulu yang dianggap sakti dimintai tolong untuk mengusir bahkan membunuh naga itu.

c. Dengan kesaktiannya, penghulu berhasil membunuh naga.

d. Si penghulu diberi imbalan tanah di daerah itu.

\section{Motif}

a. Z200: Pahlawan (Seorang penghulu menyelamatkan penduduk dari gangguan naga).

b. B870: Hewan raksasa (Naga yang mengganggu penduduk).

c. F600: Orang dengan kekuatan luar biasa (Penghulu sakti).

d. G500: Raksasa dikalahkan (Naga dikalahkan oleh penghulu).

\section{Fungsi Legenda Titah Datuak Batuah}

"Legenda Titah Datuak Batuah" mengisahkan tentang seorang datuk yang mememili kesaktian yang sangat tinggi. Karena kesaktiannya itu, ia diminta untuk mengusir serta membunuh seekor naga yang telah menimbulkan kekacauan di dalam negeri. Akhirnya, datuk itu berhasil membunuh si naga dan masyarakat pun hidup aman setelahnya. Kisah ini berfungsi sebagai sarana untuk memuji raja, pimpinan, dan orang-orang yang dianggap suci, keramat, dan berwibawa oleh masyarakatnya. Selain itu, kisah ini juga berfungsi sebagai saranan pendidikan bagi generasi penerus agar mereka bisa mengambil hikmah dari kisah yang ada. Kisah ini bermanfaat bagi mereka untuk menjalani kehidupan yang lebih baik.

\section{Kearifan Lokal Legenda Titah Datuak Batuah}

"Legenda Titah Datuak Batuah" memiliki nilai kearifan lokal yang terlihat pada sosok Datuak Batuah. Ada orang-orang tertentu yang dianggap sebagai orang yang bertuah oleh masyarakat. Orang ini dihormati dan disanjung. Keberadaannya di tengah masyarakat dianggap penting. Mereka dianggap suci, keramat, dan berwibawa oleh anggota masyarakatnya.

Artikel ini merupakan nukilan penelitian yang menitikberatkan perhatian pada pendokumentasian dan pembahasan mengenai cerita rakyat Minangkabau 
yang terdapat di di Kota Sawahlunto. Selain pendeskripsian cerita rakyat Minangkabau di Kota Sawahlunto, penelitian ini juga menganalisis motif, fungsi, dan kearifan lokal cerita rakyat Minangkabau tersebut. Setelah melakukan analisis motif berdasarkan rumusan kelompok motif yang diuraikan oleh Stith Thompson, terdapat beberapa rumusan motif cerita rakyat yang ada di Kota Sawahlunto. Motifmotif tersebut berupa 1) Motif binatang, 2) Motif tabu/pantangan, 3) Motif sihir, 4) Motif kematian, 5) Motif keajaiban, 7) Motif raksasa, 8) Motif kebijaksanaan dan kebodohan, 9) Motif penipuan, 10) Motif pembalikan keberuntungan/nasib, 11) Motif menasbihkan masa depan, 12) Motif kebetulan dan nasib, 13) Motif masyarakat, 14) Motif hadiah dan hukuman, 15) Motif tawanan dan buronan, 16) Motif kekejaman/kebiadaban, dan 17) Motif sifat/karakter.

Selain motif, penulis juga mengungkapkan fungsi sosial cerita rakyat Minangkabau di Kota Sawahlunto. Fungsi-fungsi sosial yang terungkap dalam pembahasan adalah cerita rakyat yang berfungsi sebagai sarana untuk mendidik dan memberikan pelajaran tentang kehidupan, sarana mewariskan atau meneruskan tradisi suatu bangsa dalam arti yang positif, sarana untuk mengungkapkan jati diri yang menjadikan dirinya sebagai suatu tempat di mana nilai kemanusiaan mendapat tempat yang sewajarnya, dipertahankan, dan disebarluaskan, sarana untuk meningkatkan perasaan solidaritas suatu kelompok, sarana untuk memberi sangsi sosial agar orang berperilaku baik atau memberi hukuman, sarana untuk mengekspresikan gejolak jiwa dan renungannya tentang kehidupan oleh masyarakat purba atau nenek moyang kita dahulu, sarana untuk memuji raja, pemimpin, dan orang-orang yang diangggap suci, keramat, dan berwibawa oleh kolektifnya.

Nilai kearifan lokal yang terungkap di dalam cerita rakyat Minangkabau di Kota Sawahlunto, yaitu 1) Alam bisa menjadi sumber inspirasi penamaan suatu daerah, 2) Kesombongan dan kesewenang-wenangan akan mendatangkan kehancuran bagi orang yang bersangkutan. 3) Orang yang berbuat semena-mena terhadap mereka yang lebih lemah pada saatnya nanti akan mendapat ganjaran dari perbuatan buruknya itu, 4) Orang yang dianggap lemah belum tentu mereka selamanya lemah. Suatu saat, mereka akan memiliki kekuatan untuk meruntuhkan kesombongan dan perbuatan semena-mena, 5) Terdapat zat lain selain manusia, ada makhluk lain yang juga menjadi makhluk ciptaan Allah. Dialah jin yang diciptakan oleh Allah untuk menguji keimanan manusia, 6) Setiap percecokan atau pertengkaran yang terjadi di dalam suatu hubungan, baik di dalam sebuah keluarga maupun di dalam sebuah masyarakat hanya akan mendatangkan kerugian bagi mereka sendiri. Hidup damai antar sesama manusia tentu menjadi pilihan yang lebih baik untuk dijalani sehingga akan mendatangkan kehidupan yang aman, damai, dan tentram, 7) Kesetiaan sangat diperlukan dalam sebuah hubungan, baik hubungan antar individu maupun hubungan antar kelompok dalam suatu masyarakat, 8) Setiap kejahatan pasti mendapat hukuman, 9) Semua bentuk penjajahan di atas bumi ini tidak sesuai dengan peri kemanusiaan dan peri keadilan. Penjajahan hanya akan mendatangkan keburukan bagi mereka yang terjajah.10) Kebodohan akan mendatangkan kerugian, sebaliknya kecerdasan dan keinginan untuk belajar akan mendatangkan keuntungan yang berlipat ganda, 11) Kesetiaan sangat penting di dalam kehidupan. Orang yang setia akan mendapat penghargaan dari orang lain, 12) Kebaikan akan mendapat balasannya. Balasan itu dapat 
diperoleh secara nyata maupun didapat secara gaib, 13) Kepercayaan terhadap tokoh-tokoh masyarakat yang dianggap bertuah dan memiliki kesaktian, dan 14) Pelanggaran terhadap suatu aturan akan mendatangkan akibat yang tidak baik bagi yang bersangkutan.

\section{PENUTUP}

Berdasarkan analisis yang telah dilakukan sebelumnya, penulis sampai pada kesimpulan bahwa cerita rakyat Minangkabau yang terdapat di Kota Sawahlunto, Provinsi Sumatra Barat memiliki motif yang beragam berdasarkan rumusan kelompok motif yang diuraikan oleh Stith Thompson. Selain motif, cerita rakyat tersebut juga memiliki fungsi dan nilai kearifan lokal yang dapat dijadikan acuan dan pedoman bagi masyarakat untuk memperbaiki kehidupannya dengan berpedoman kepada nilai budaya dan tradisi masyarakat Minangkabau.

\section{DAFTAR PUSTAKA}

Atmazaki. (2007). Ilmu Sastra: Teori dan Terapan. Padang: UNP Press.

Caroline Nyamai-Kisia. (2010). Pengertian Kearifan Lokal. Diakses pada 6 Desember 2017, dari www.psychologymania.com/ 2012/11/pengertiankearifan-lokal.html

Danandjaya, James. (2002). Folklor Indonesia: Ilmu Gosip, Dongeng, dan LainLain. Jakarta: PT Pustaka Utama Grafiti.

Echols, John M. dan Shadily, Hassan. (2005). Kamus Inggris Indonesia : An English - Indonesian Dictionary. Jakarta: PT Gramedia.

Endraswara, Suwardi. (2009). Metode Penelitian Folklor: Konsep, Teori, dan Aplikasi. Yogyakarta: Med Press.

Gayatri, Satya dkk. (2008). Pendokumentasian, Pengarsipan, dan Penerbitan Folklor di Kabupaten Limapuluh Kota. Padang: Program Studi Bahasa dan Sastra Minangkabau.

Gobyah. (2003). Pengenalan Kearifan Lokal Indonesia. Jakarta: Rineka Cipta.

Hamidy, UU. (2003). Bahasa Melayu dan Kreativitas Sastra di Daerah Riau. Pekanbaru: Unri Press.

Koentjaraningrat. (2000). Pengantar Ilmu Antropologi. Jakarta : Rineka Cipta.

Pudentia. (2008). Metodologi Kajian Tradisi Lisan. Jakarta: Asosiasi Tradisi Lisan. Semi, Atar. (1984). Anatomi Sastra. Padang: Sridarma.

S. Thompson. (1955). Motif-index of Folk-Literature : a Classification of Narrative Elements in Folktales, Ballads, Myths, Fables, Medieval Romances, Exempla, Fabliaux, Jest-Books, and Local Legends. Bloomington : Indiana University Press.

Sudikan, Setya Yuwana, (2001). Metode Penelitian Sastra Lisan. Jakarta: Bentara Budaya. 